\title{
Some Effects of Unstructured Outdoor Plays on a Child: A Case Study from New Zealand
}

\author{
Emel Okur-Berberoglu* \\ LIC (Livestock Improvement Corporation), Hamilton, NEW ZEALAND
}

\begin{abstract}
Outdoor education is one of the popular subjects in education recently and used synonymously with different concepts such as adventure education, nature education, museum education, recreation education or experiential education. It is also considered as complementary of mainstream education and a rich learning environment by the researchers. The literature mentions different positive outputs of outdoor plays. There are not many studies related to unstructured outdoor plays. The aim of this study is to determine some effects of unstructured outdoor plays on a child in New Zealand. Qualitative approach is used within a case study. The defined themes at the end of the study are observing, exploring, cognitive development, creativity and self-confidence. It is needed more experimental studies with control groups.

Keywords: Unstructured outdoor plays, outdoor education, preschoolers, New Zealand.
\end{abstract}

\section{Introduction}

Outdoor education is one of the popular subjects in education recently and used synonymously with different concepts such as adventure education, nature education, museum education, recreation education or experiential education (Okur, 2012; OkurBerberoglu, 2015a). Outdoor education is also considered as complementary of mainstream education. (Brodin\& Lindstrand, 2006) Brodin and Lindstrand (2006:17) explain outdoor education as "... can be used to describe activities going on outdoors and our philosophy of learning is that learning takes place in all situations and contexts where a human being is involved. This means that there are no situations in real life where learning does not take place." Brodin and Lindstrand (2006:17) mean that the definition of outdoor education might change according to research's context, aim and how researcher conducts the study. The contexts of outdoor education might be classified under six titles: Learning \& education, Wilderness \& nature, Psychoexperimental activities, Psycho-social aspects of outdoor education, Facilitation in different contexts outdoors and Multi-dimensional aspects (Brodin\& Lindstrand, 2006: 18). The philosophical perspective of outdoor education might be effective on having these different outputs (Okur-Berberoglu, Guder, Sezer\&Yalcin-Ozdilek, 2013).

\section{Theoretical Framework of Outdoor Education}

It is stated that the roots of outdoor education philosophy are based on Comanius, Rousseau, Pestalozzi and Dewey (Hammerman, Hammerman, Hammerman 1994 in Shanely 2006). It is thought that Rachel Carson might also be added to this list. Comanius, Rousseau and Pestalozzi, who are $16^{\text {th }}$ and $17^{\text {th }}$ century philosophers, are accepted pioneers of modern education system although they had religious education (MacCulloch, 2009). Comenius says that every child even before starting to school should interact with a rock, a flower or an animal in order to understand a natural subject (Hammerman, Hammerman, Hammerman 1994 in Shanely 2006). According to Rousseau, children can learn best from their direct experiences from the natural environment and this learning primarily comes from nature, people and objects around 
the child. Rousseau emphasizes that our first teachers are five senses because we can perceive and experience the natural environment by our five senses. These experiences help us to transfer our acquisitions to long-term memory. (Brodin\& Lindstrand, 2006; Kraft\& Kielsmeier, 1995) Pestalozzi emphasizes that first-hand experiences are important for children, too. Adults should not answer children's questions directly; they should mentor children in order to experience and discover. Children, therefore, might be able to develop heuristic learning. (Stine 1997; Siraj-Blatchford\& Macleod-Brudenell, 1999). Carson (1956) also points out that learning happens when children use five senses which can open children's disused sensory channels. According to Carson (1956) and Louv (2005), people have lost their learning ability by using five senses throughout the evolution and because of modern lifestyle with technology and media. Later, all these ideas are combined with Kolb's Experiential Learning Theory. Kolb (1984) defines experiential learning as a transformation process of knowledge in mind which happens by different first-hand and hand-on experiences. Kolb's perspective mostly reflects the cognitive side of outdoor education. However, there are different kinds of outputs for outdoor education (Okur-Berberoglu, 2017).

In terms of educational perspective, Waite (2009) classifies the aims of outdoor education under three categories: physical wellbeing, social and emotional wellbeing, different kinds of learning. Cooper (2015) evaluates outdoor education regulation in the USA in her article and arrays benefits of natural outdoor learning environment as:

- Improves self-regulation

- Advances physical fitness and gross motor development

- Improves nutrition

- Improves eyesight

- Promotes cognitive development

- Improves academic performance

- Lessens the symptoms of ADHD and improves concentration

- Promotes self-confidence

- Builds understanding and appreciation of ecosystems, food systems, and environmental processes. (Cooper, 2015:2)

In terms of child development, early childhood educators and researchers emphasize that these outdoor education outputs are very important for preschoolers because early childhood education (ECE) has huge effect on the later stage of adulthood (Brodin\& Lindstrand, 2006) especially in terms of creativity (Louv, 2005).

\section{Literature Review for Preschoolers and Outdoor Learning}

Outdoor education might help children to awe, wonder and enjoy therefore children should experience outdoor activities and education in their early years (Carson, 1956; Wilson, 1996). There is no need to direct children. It is enough to let them to be exposed outdoors' magic environment according to Carson (1956). When children observe and explore something outside, they will have an emotional connection with things at the first stage; later they would like to learn about what they sense on their own (Carson, 1956). Wilson (1996) also says that there should not be a strict education programme for children because they cannot concentrate on something very long. Children, therefore, should be encouraged to discover whatever they find interesting. Teacher should be a mentor or facilitator and present some tools children to discover them natural environment. 
Waite (2009) tries to determine outdoor learning opportunities of 2-11 years-old children in the UK. She collects her data by a survey and some educators say that they are not able to use outdoor environment because of health and safety issues. According to her results, outdoor learning experiences of preschoolers in UK appear to be a trend for decline. However, childminders support outdoor learning environment and think that outdoors give preschoolers more discovery opportunities. One of the educators says, "Learning outdoors can add awe and wonder to knowledge and experience." (Waite, 2009:8). UK government and institutions support outdoor learning settings however teachers and educators do not know how to use outdoors properly. The other important issue is there is a gap between educational aims and measurement of outdoor learning (Waite, 2009). Waite (2009) emphasizes that UK government initiatives should prepare a guide to show how to use outdoors and how to measure outdoor learning.

Friedrich Wilhelm Fröbel (1895) who is creator of kindergartens emphasizes that children should play whatever they want, and these play activities should be free from adult influence. Outdoors give children a rich learning environment and to test their boundaries. According to Brodin and Lindstrand (2006)'s report, outdoor activities are not evaluated as a learning environment despite the fact that outdoor learning is emphasized in Sweden's early childhood education curriculum. There are some studies related to outdoor education however research which aims preschoolers and outdoor education is very limited. This means preschooler and outdoor education combination is overlooked by researchers and educators. Outdoor education is mainly used at forest preschools in Sweden. However, these preschools have been criticized in terms of saving money on children because they exclude the regular school premises from the budget. Karin Engdahl (2005 in Brodin\& Lindstrand, 2006) suggests conducting further studies in order to understand what preschoolers learn from outdoor play. (Brodin\& Lindstrand, 2006)

There are some studies related to preschoolers. However most of them are based on the connection with the natural environment of preschoolers (McClain \& VandermaasPeeler, 2016; Vandermaas-Peeler\&McClain, 2015; Louv, 2005; Conezio \& French, 2002) in the USA and they find favourable effects of outdoors on the environment insight and science education of children. Louv (2005) emphasizes many positive outputs of outdoors for American students in his book. One of these outputs is creativity especially for preschoolers but this inference for preschoolers is mostly based on his observations. However, he says it is not known yet what the influence of unstructured natural landscape and experiences in nature on human development and health (Louv, 2005: 46). Louv (2005: 306) says we need controlled experimental studies in order to understand child-nature relation. It might be summarised Louv's outdoor interference for preschoolers as:

Unstructured nature + unstructured play-> having fun + self-confidence + creativity (exploring/ observing) + awareness + emotional connection to the land + learning

Some of the studies aim to determine outdoor and indoor physical activity levels of preschoolers in Sweden and the USA, especially in terms of health issues such as obesity (Raustrop et al, 2012). They find outdoor activity levels are higher than indoor activity levels and the researcher suggest that educator should encourage preschoolers for outdoor activities. There are different kind of outdoor studies based on preschoolers in Sweden (Engdahl, 2005; Brodin\& Lindstrand, 2005; Lindstrand, 2005), Australia (Cullen, 1988) and Turkey (Yıldırım \& Akamca, 2017). They find that outdoor activities stimulate preschoolers' gross-motor, social, dramatic and constructive play developments and preschoolers might learn the names of new objects which they have encountered for the first time. However, these studies are conducted on preschools' yards or playgrounds (Cullen, 1988; Engdahl, 2005; Brodin\& Lindstrand, 2005; Lindstrand, 2005) or the teachers carry out a structured education programme for preschoolers (Yıldırım \& Akamca, 2017). 
Outdoor education is accepted an important part of preschoolers in New Zealand (NZ) (Stephensen, 1999; McLachlan, 2013; Ministry of Health, 2017). Some of the studies related to preschoolers and outdoors are based on determination of physical activity levels of children (Oliver et al, 2007; Oliver, 2008; Ku, 2011; Young, 2017). These studies are closely associated with health issues such as obesity (Gerritsen, 2016; Young, 2017), cardiovascular disease, type 2 diabetes, bone health (Oliver et al, 2007; Oliver, 2008; Ku, 2011; Ministry of Health, 2017) or sun protection (Duignan et al, 2014). These studies also suggest that early childhood education centres should present more outdoor times and activities for preschoolers (Oliver et al, 2007; Oliver, 2008; Ku, 2011; Gerritsen, 2016; Ali et al, 2017; Ministry of Health, 2017; Young, 2017) but they should also consider protection from sun light while having outdoor activities (Duignan et al, 2014). Stephenson (1999) observes forty-five children in indoor and outdoor environments of a childcare centre. She finds physical and cognitive positive outputs for outdoor activities. However, all those studies above are based on the playgrounds or gardens of the centres or kindergartens.

Burke (2008), emphasizes multicultural population of NZ and compares NZ- Japan early childhood education centres in terms of pedagogical differences. Holdom (2018) and O'Brien (2015) evaluates Te Whāriki early childhood education programme of New Zealand in terms of science-mathematics-technology education while Kumar \& Whyte (2018) evaluates Te Whāriki science education in terms of sociocultural environment. These researchers suggest using outdoors for hand-on experiences however their studies are at the theoretical level.

Louv (2005) emphasizes many positive outputs of outdoors for students in his book and asks, "What do we know the influence of unstructured natural landscape and experiences in nature on human development and health?" (Louv, 2005: 46). Karin Engdahl (2005 in Brodin\& Lindstrand, 2006) also suggests conducting further studies in order to understand what preschoolers learn from outdoor play. The aim of this study, therefore, is to evaluate the effect of unstructured outdoor plays on a child in New Zealand (NZ).

\section{Methodology}

The case study based on qualitative methodology was used in order to collect data and analyse the results of them. The preference for the case study was due to its usefulness in terms of collecting enough data (Yildirim \& Simsek, 2006), and for yielding descriptive and explanatory results (Forces \& Richer, 1973 in Zanovello, 1999; Stufflebeam, 2001). In terms of establishing the research's reliability, the qualitative analyses were supported by the triangulation data collection method, which included: non-participant observations by an ECE teacher and a parent. They shared their observation notes on the StoryPark online communication module (Yildirim \& Simsek, 2006; Zanovello, 1999).

\section{NZ Early Childhood Education Programme (Te Whāriki)}

New Zealand early childhood education curriculum is named as 'Te Whāriki'. This curriculum is defined as 'mat for all to stand on' (Te Whāriki, 2017:10) and based on Maori philosophy (Hemara, 2000). It has four principles and five strands. Principles are empowerment, holistic development, family and community and relationships. Strands are wellbeing, belonging, contribution, communication and exploration (Table 1). (Hemara, 2000; Te Whāriki, 2017) 
Table 1.

The principals and strands of Te Whāriki

\title{
Te Whāriki
}

\author{
Principles \\ Strands \\ Empowerment \\ Wellbeing \\ Holistic development \\ Belonging \\ Family\& Community \\ Contribution \\ Relationships \\ Communication \\ Exploration
}

Children are seen as confident and competent learners from birth according to Te Whāriki and can learn by meaningful interactions with people and places. This learning process goes on throughout children's lives. (Hemara, 2000) There is not any proper activity definition in Te Whāriki.

ECE teachers -also named as kaiako- should decide their activities according to principles, strands, children's background, interest, competency and needs (Empowerment). ECE teachers should also be aware of how children's developments happen holistically. Activity aims should consider cognitive, physical, affective, spiritual, cultural and social developments all together because these developments happen interwoven and independent (Holistic development). Children can learn through responsive and reciprocal relationships with people and places therefore ECE teachers should promote rich learning environments for being realised these relationships by children (Relationship). In these rich learning environments, explorations, gaining confidence, problem solving, testing physical boundaries and meaningful learning happen if children play spontaneously (Exploration). Children can also learn where they belong to in the rich learning environments (Belonging). (Hemara, 2000; Te Whāriki, 2017). The bush explorer activity is based on Te Whāriki.

\section{The 'Bush Explorer' Activity}

The bush explorer activity has been run by a kindergarten in New Zealand for four years. This is a programme that runs for a term ( 10 weeks, between $3^{\text {rd }}$ of May and 5 of July in 2018) with the same 8-12 children around 3.5- 4 years-old. The children go into the bush with an ECE teacher and two parent helpers on morning once a week and on the same day. The same teacher and and parent helpers go in each week for the term. The bush is in the reserve where the kindergarten is situated in. It takes 2-3 minutes to walk there on the grass.

\section{What Happens in the Bush?}

The activity is play-based, child initiated and child lead. There are basic safety rules which are explained by adults at the beginning of the activity however there is no programme set by adults. The children are free to follow their own play, how and when to play. The children themselves decide the rules of their plays and the roles they take 
within their play. The play is intrinsically motivated; they do it because they want to, not because they are told they have to. The play varies from group to group and week to week. The play-based learning for many children grows and develops over the time in the bush. Adults responsibilities in the bush are to promote a safe environment, to follow and support the children's play.

\section{How Does the Activity Work?}

- The children gather in the kitchen of the kindergarten and prepare for the bush. This includes getting suitable water-proof gears and footwear on and getting children bags.

- The teacher chooses a child as a rangatira (leader in Maori) and this child leads the group.

- The adults take into the bush a bag of equipment including mobile phone, camera, first aid kit, wipes, bug spray, ice pack, tarp, magnifying glasses, clipboards, pens, robes, potato peeler, torches.

- The children who are leaving the kindergarten are marked on the roll and the group walks together to the edge of the bush.

- The group, especially rangatira, asks for permission from Tane Mahuta to enter the bush and waits for a reply from birds. Tane Mahuta is the god of forests and of birds, and the son of Ranginui and Papatūanuku, the sky father and the earth mother. The sign might be the singing tui.

- Then the group go into the bush, set up a base camp and leave their bags.

- Some groups might gather for a little mat and some might go off to play or eat. This depends on the group. The adults assess the needs of the group and make decisions in consultation with the children accordingly. The children are often keen to involve the adults in their discoveries and plays.

-The activity takes about two hours. At the end of the time, the group gathers everything. -They may share their day, a story, or just pack up (depending of the needs of the group).

- When leaving, the group and the rangitara thank Tane Mahuta for allowing us to play in the bush.

- The group return to kindergarten where they get out of the bush.

- All group comes back to kindergarten after two hours.

The Roles of the Researcher

The researcher had three roles: within this study:

a. Activity planner: The researcher holds $\mathrm{PhD}$ degree in outdoor education. The participant of the study was a four-year-old girl who was named as 'Emily' within this study and this girl was my daughter. As a mum I have been observing my daughter since her birth and encouraging her to play in outdoors. Whenever we had time we preferred to go outdoors, and she usually had unstructured plays. I always had a lunchbox, spare clothes and usually had a magnifying glass. She played on the playgrounds, in or by the river or on the beach. Me and my daughter usually preferred to walk therefore my daughter had opportunities to observe the outside world.

b. Facilitator: The researcher occasionally facilitated the participant while she was observing or playing in terms of how to do something.

c. Non-participant observer: The researcher was an observer throughout the outdoor times. In order to enhance the observation, activities were recorded by photographs and observation notes. 
Observation started in November, 2016

\section{May,2018 July,2018}

Bush explorer
Observation finished in November, 2018

Figure 1. The timetable of the research

\section{Data Collection and Analysis}

There were two observers within this study. One of them was the researcher and she observed the participant for two years because the participant mostly preferred unstructured plays in outdoors. The other observer was an ECE teacher who was responsible for the 'bush explorer' activity. The activity was designed according to Te Whāriki's principles and strands. The teacher observed the participant for 10 weeks and took some notes and photographs during the activity. (Figure 1) She wrote down her observations on the Story Park online communication tool in order to share them with the researcher.

Two observers' notes were combined on the computer and analysed by content analysis. Two independent researchers coded independently these notes. Codes and themes were defined according to the content analysis. The coherence of these two evaluations were determined by Cohen's kappa index. This index is used in order to understand the coherence between two or more independent evaluations and it should be at least between $0.60-0.70$ in order to have satisfactory coherence (Wood, 2007). Cohen's kappa index is also calculated on SPSS 15 programme. The Cohen's kappa index of this research was 0.67 . In other words, the coherence of two researchers was at the satisfactory level.

\section{Findings}

At the end of the analysis, five themes were defined: Observing the nature, exploring, cognitive development, creativity and self-confidence.

\section{Observing nature}

Both the teacher and the researcher mentioned how the participant observed the natural environment carefully. The teacher's observation belonged to week 10:

"Emily has continued and deepened a love and respect for nature and the environment and has built upon her knowledge and understandings through the legends of Maui and his adventures such as How Maui found his mum, How Maui found his dad \& the magic jawbone and In the beginning. Both first two legends featured a Kereru/wood pigeon which we spotted high up in the trees above in the tree tunnel on the way into the bush. In the legend, the wood pigeon was called a Rupe. We also noticed this Kereru/Rupe in the bush each week. I think this Kereru/Rupe was watching over us as we explored and discovered this new environment - so magical and beautiful. We have also seen a Kereru/Rupe back at kindergarten and wonder if it is the same one. During the last week of the term back at kindy, we made bird feeders to say thank you to the Kereru/Rupe for visiting and watching over us.

"Emily has extended her respect and a sense of responsibility for the well-being of both the living and non-living environment through the care and consideration taken with leaving the bush as we found it e.g. taking our rubbish back to kindergarten and leaving treasures found behind in the bush. "

The researcher's observation was coherent with the teacher's observation: 
"I think unstructured outdoor plays triggered my daughter's observation ability, too. One of her main activity was to climb up the tress (Photograph 2) and find bugs on the tree. This activity happened randomly.

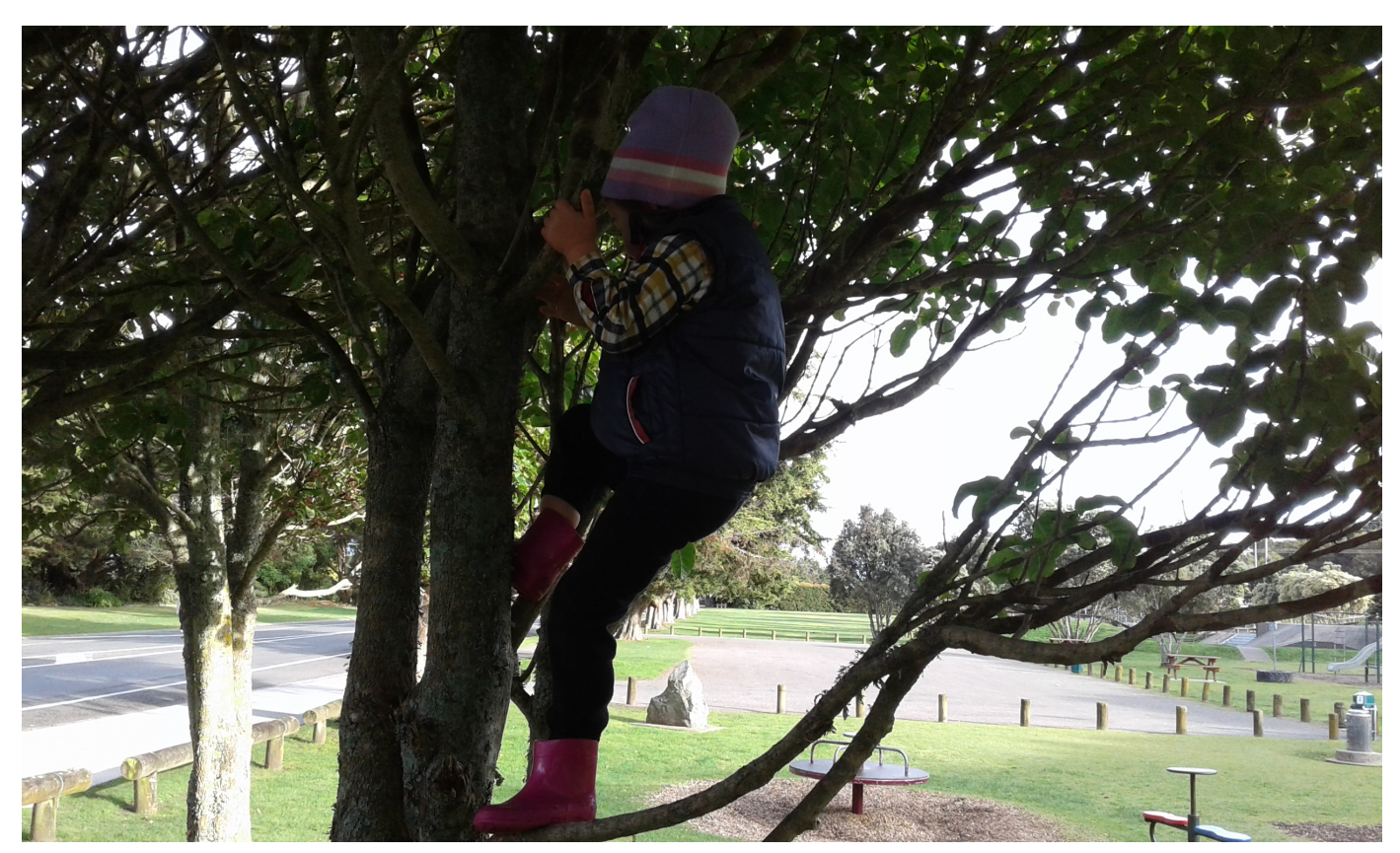

Photograph 2. While climbing up a tree

She usually looked for spiders or cobwebs in the tree. Later she realised there were ladybugs, bugs and ants underneath barks. She liked to observe them. A couple of times, she peeled the bark off and tried to understand where they went to.

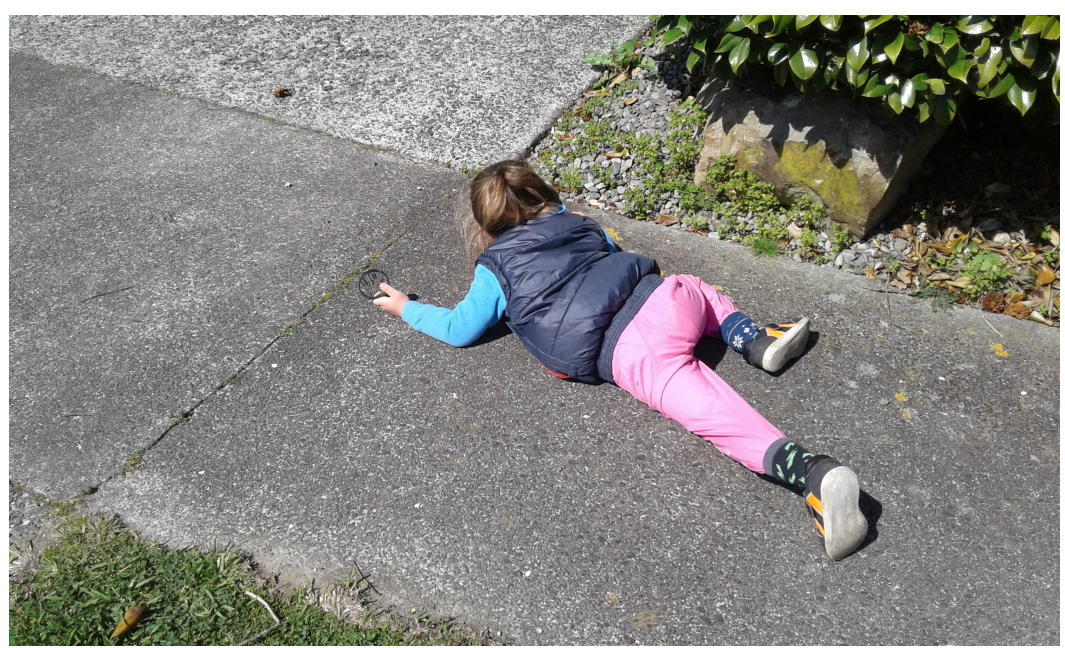

Photograph 3. While observing ants 
Some ants made a way themselves from the tree to the pavement. My daughter lied down with her magnifying glass and observed their walking way. (Photograph 3 ) One another day, she saw a Pukeko standing on a log while observing ants.

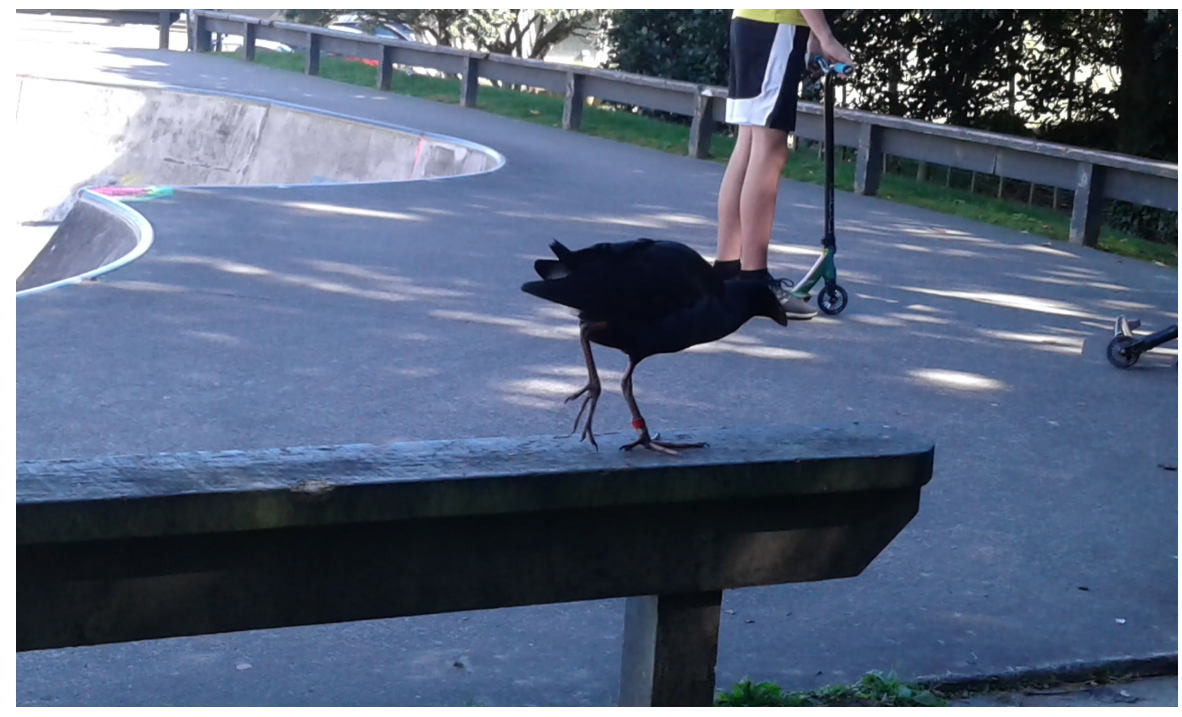

Photograph 4. While chasing native bird Pukeko

The known name of this bird is swamphen. Pukeko is its local Maori name and a native bird for New Zealand (New Zealand Birds, 2018). My daughter wanted to pet and chased it. (Photograph 4) She could not catch it but then again, she tried. She said she wanted to take it home and nurture it.

One another day she saw a dead Tui in the meadow while walking in the outdoors. Tui is an endemic bird for New Zealand, its voice is very nice and has very typical white feathers on the throat (New Zealand Birds, 2018).

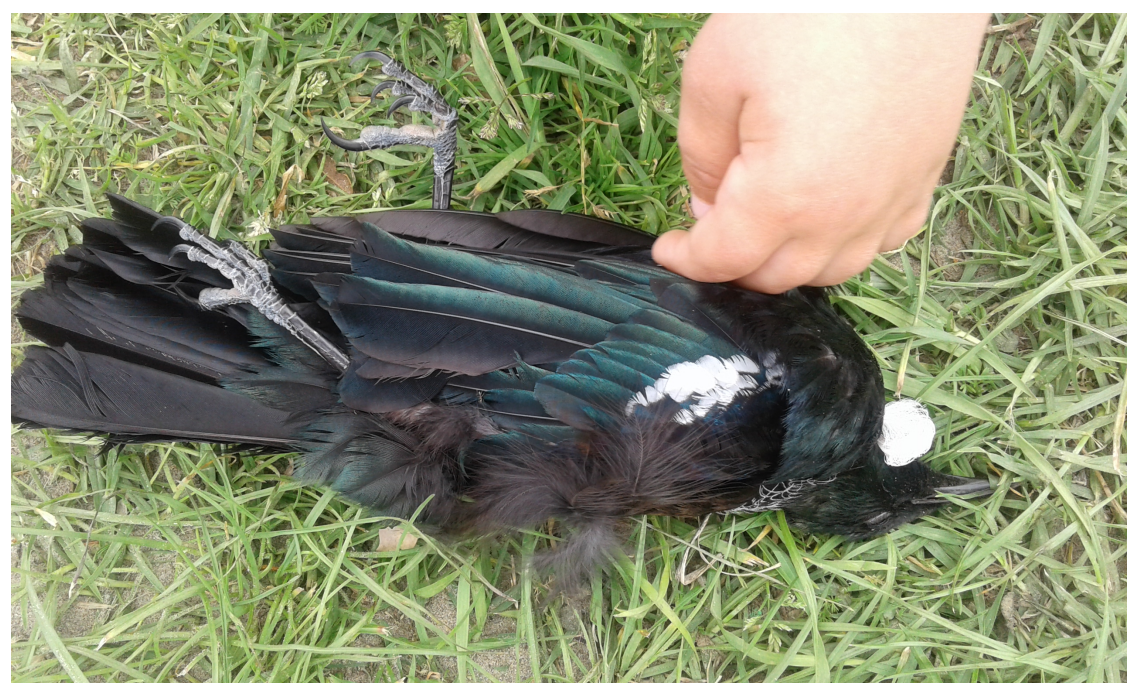

Photograph 5. While patting dead Tui

My daughter suddenly wanted to cuddle Tui. (Photograph 5) I explained it was dead. She checked it and started to pat it. Later she realised it did not move. I said we had to go, she blew a kiss to Tui and left it. When we left Tui, my daughter saw a snail on a log. She grabbed and started to observe it. 


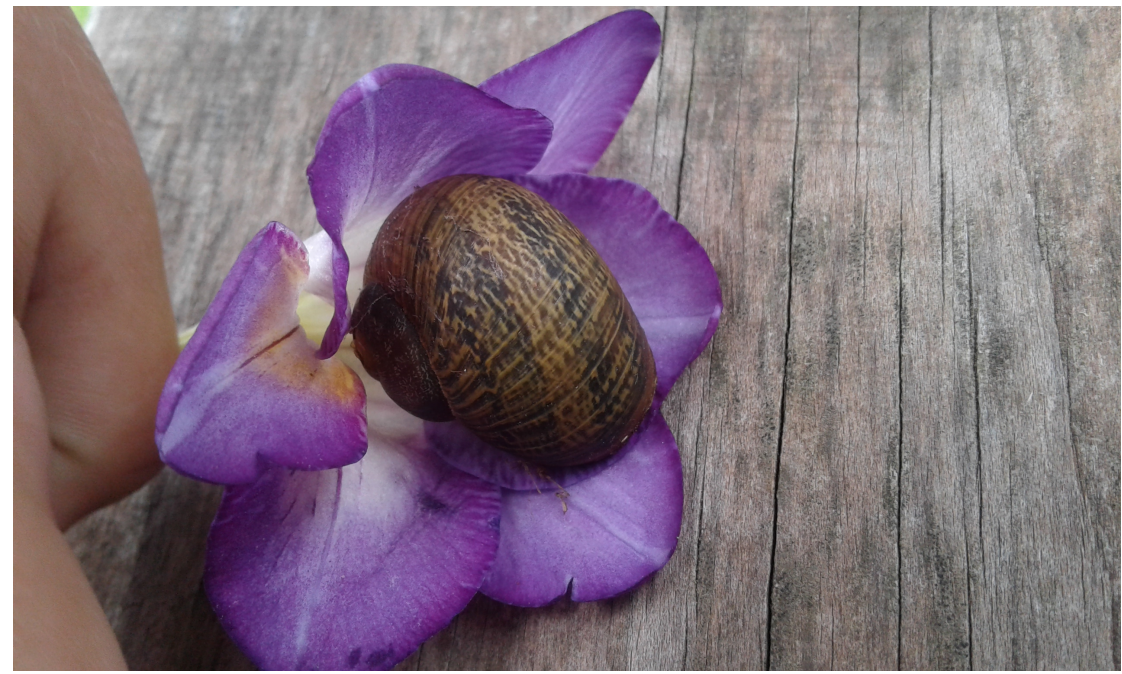

Photograph 6. A snail nest

She found a flower in the meadow and put the snail into the petals. She said she made a 'nest' for the snail and this nest would protect it from cold. (Photograph 6) I did not show her anything related to a Tui or a snail, but she was very interested in natural environment. As Carson (1956), Wilson (1996) and Louv (2005) said before, outdoors give awe, wonder and enjoy to children.

One another unstructured play area for us was seaside. Children usually like to play on the sand or splash the water. So does my daughter. Even the weather is windy or cold, she likes to play on the sand and digs a hole. (Photograph 7)

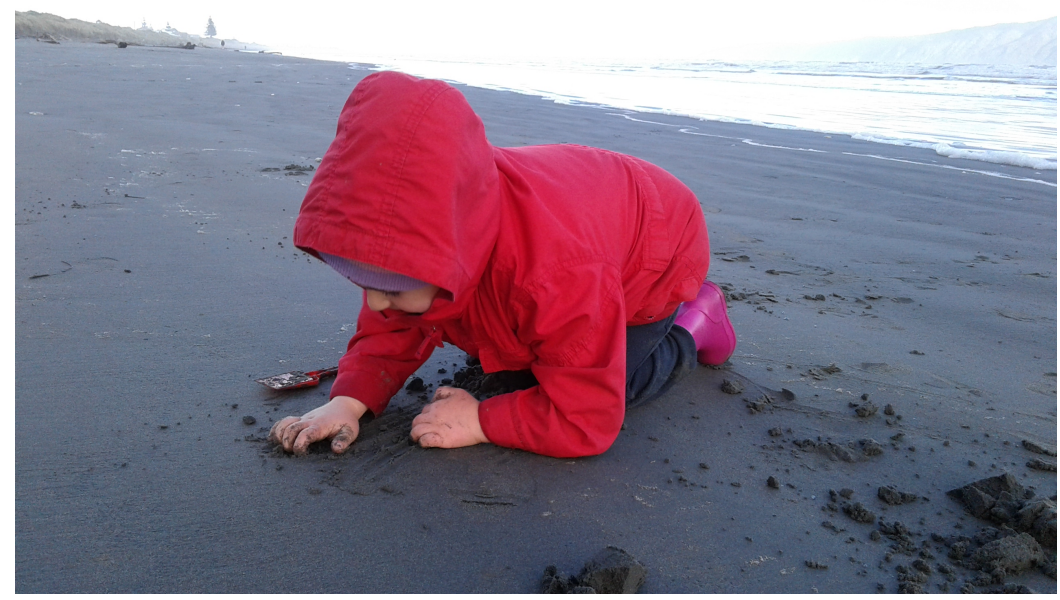

Photograph 7. While playing on the beach

The other unstructred play on the seaside was to run away from the waves. First, she followed the waves to the sea and later, she tried to run away from the waves. Of course, she could not outrun the waves but that was the fun part of the game. She could not outrun and jumped in the waves. 


\section{Exploring}

One of the important results of the study was exploring. The teacher noted her observations in week 1 (3 May) and week 10 (5 July) as:

"Emily discovered lots of creatures. You eagerly discovered lots of creatures/insects which you enjoyed immensely. The magnifying glasses and torches proved to be your favoured tools in the bush. ...., throughout your time in the bush you have strengthened the disposition (habits of mind) of investigation throughout many different experiences and situations aptly and easily transferring your competence and knowledge continuity."

"Lots of great ideas and creativity again this week. Emily found some spikey things and said, "don't touch" and "this is what caterpillars eat to turn into butterflies. Emily has gained confidence and control of her body through developing strategies or actively exploring and making sense of the bush environment by using her body, including active exploration with all her senses and the use of tools, materials, and equipment to extend her skills through rope climbing, fossil hunting, navigating through tight spaces and the use of peelers, magnifying glasses and torches. This was extended further through making our own bush rope swing in which we all had a turn."

The researcher's observation notes belonged to a river activity.

"My daughter likes to find river creatures. This play is very easy. All we need is a magnifying glass and a little basket. (Photograph 8)

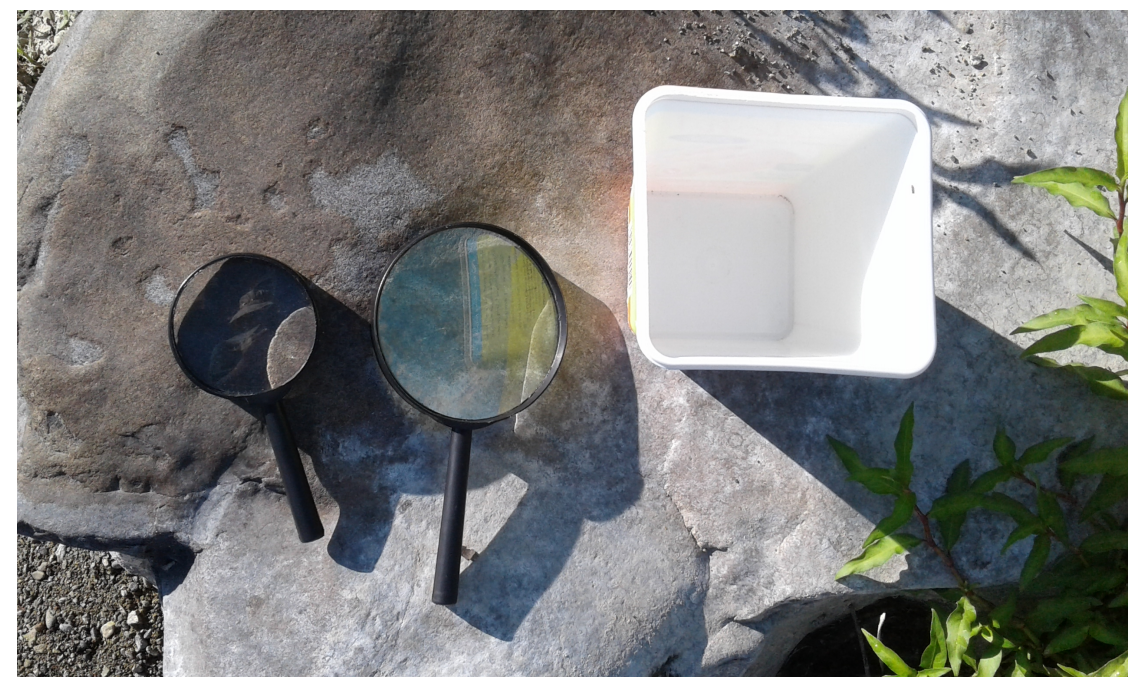

Photograph 8. Activity materials

I showed my daughter how to do the activity and later, she did every step by herself. The first step is to scoop water into the basket from the river. The second step is to pick up a little rock from the river. (Photograph 9 and 10) 


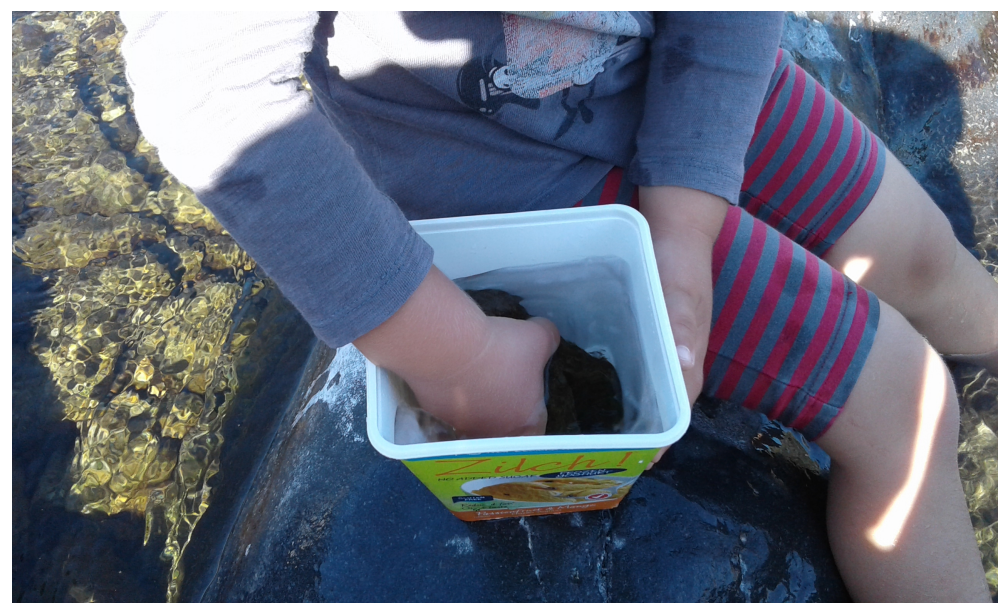

Photograph 9. The third step is to shake the rock in the basket

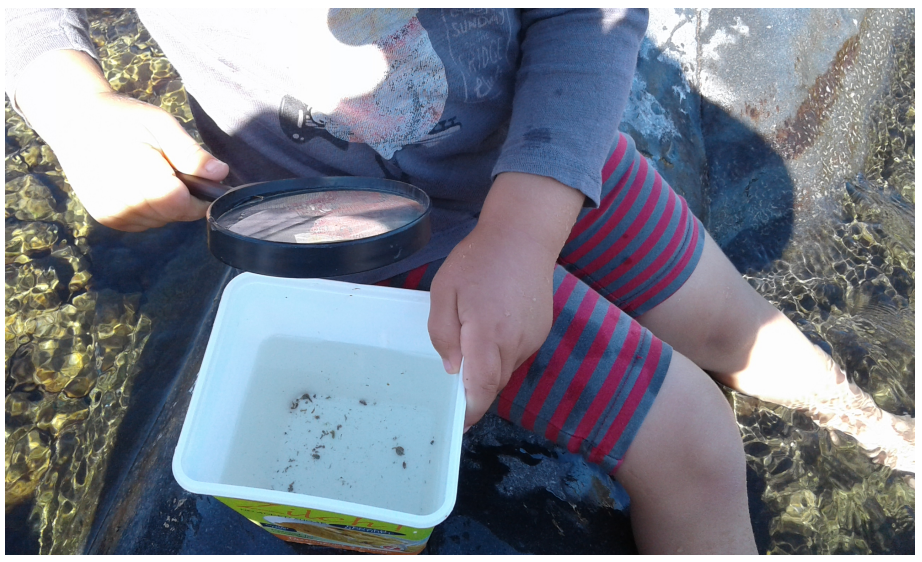

Photograph 10. The fourth step is to look for river creatures

Actually, there is no river creature. My daughter found mollusc, tadpole, caddisfly and damselfly larvaes. My daughter named them as a creature because preschoolers are not able to understand technical terms. Here are some examples from what my daughter found: (Photograph 11 and 12)

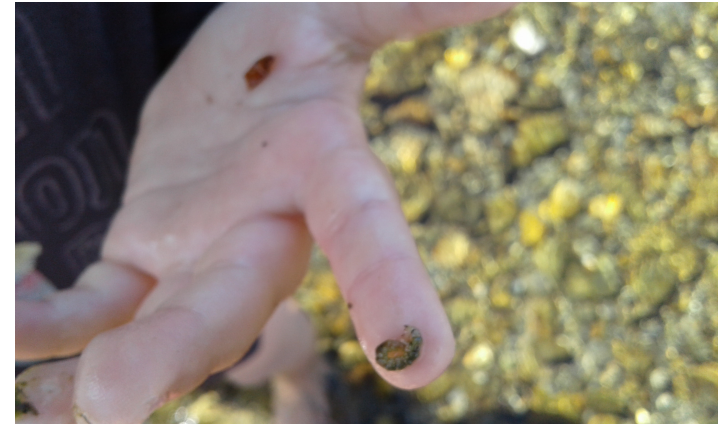

Photograph 11. Caddisfly larvae

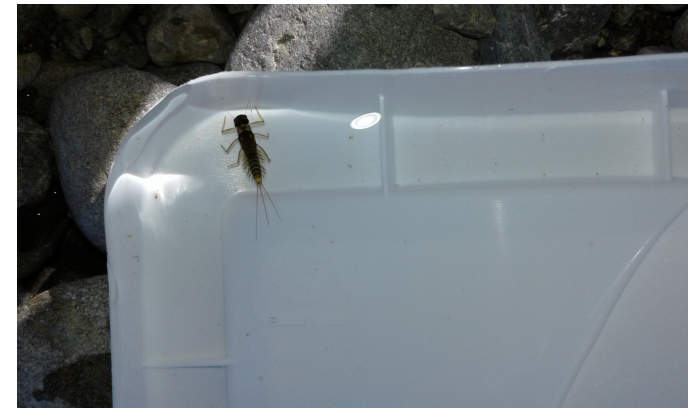

Photograph 12. Damselfly larvae 
She was so excited, amazed and surprised when she saw these creatures because they were moving and wiggling. She did not expect any creature underneath rocks in the river. If the weather was fine, this activity became our routine activity every weekend or everyday, after the first experience. She said to me "Let's go and find river creatures Mommy!". I was delighted seeing my daughter's excitement. As an outdoor researcher, it is so nice to see practical side of outdoor education in terms of preschoolers. There are academic papers related to preschoolers and outdoors. However, they are mostly based on theoretical perspective. They also emphasize the same points: outdoors, awe, exploring, observing, sentimental connection and cognitive development.

\section{Cognitive development}

One another observation theme was cognitive development by the researcher:

"The river activity was a structured outdoor play at the first stage but later, it became an unstructured outdoor play. Time to time, my daughter played with sand by the river, chased the ducks in the river, threw the rocks to the river or tried to get floated something on the water. This rock game was also a kind of competition between us.

We competed each other who would throw the rocks further away. I picked up the light rocks so I could throw further away. My daughter picked up heavy rocks because firstly, she was interested in splashing the water. Later she observed my rocks and started to pick up light and little rocks. I think this was a learning curve for her. I did not aim to teach her something explicitly, but she learned to pick the little rocks up to reach the further distance.

My daughter also tried to get floated rocks on the water, and of course she could not succeed. I asked me why she could not succeed it. I said, "give it a try once more". She started to play to find river creatures, suddenly she dropped the basket onto the water and chased the basket to catch it up. In the meantime, she realised it was floating. Later, she tried different subjects to get floated: a little stick or a little branch. "(Photograph 13)

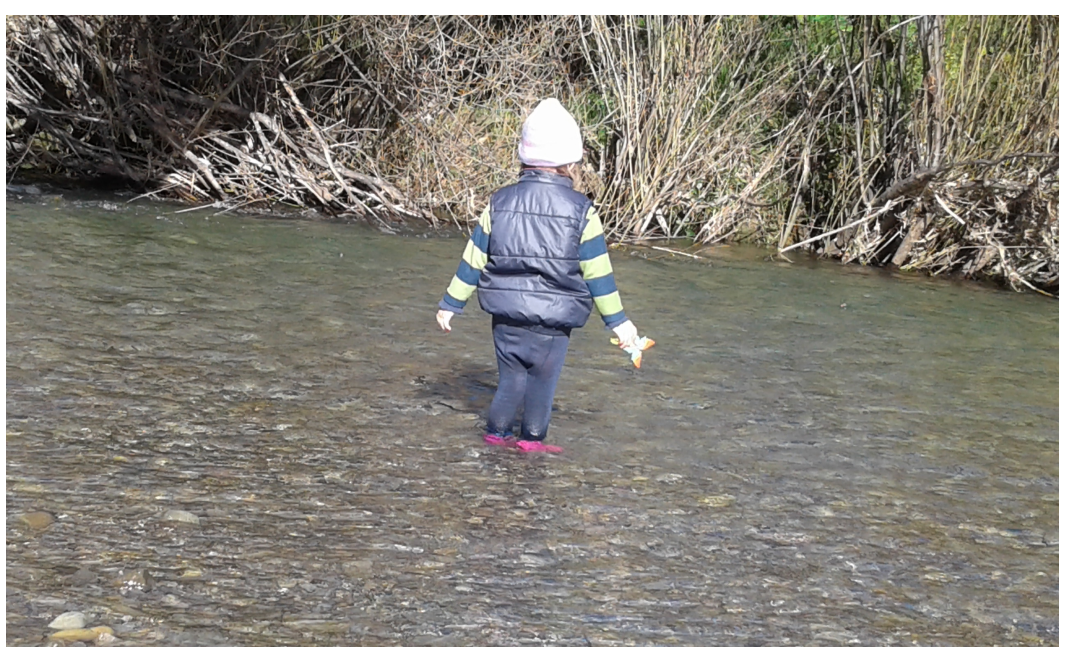

Photograph 13. While playing in the river

\section{Creativity}

One of the major outputs of the study was creativity. The teacher and the researcher mentioned how the participant's creativity improved by the time. The teacher's observation belonged to Week 8 (21 June) 
“.... spent quite some time drawing horses while Emily spent time drawing with charcoal. We had charcoal and cartridge paper and some lovely coloured pencils available today.

Emily, you worked out how to best use your time to explore and enjoy all the awe and wonderment of the bush. Your confidence and enjoyment in the bush have just grown and grown. The bush has provided a platform of more magical excitement and discovery for you. You were able to further develop your creative and imaginative skills through your pretend play with ...... and your imagination with the spikey things. You made sense of the legends - working theories in action. "

The researcher's observation was based on the participant's drawings, too:

"I realised unstructured outdoor plays have also affected my daughter's art and imaginations. My daughter has drawing staff like every child. Sometimes she prefers to draw something on her own.

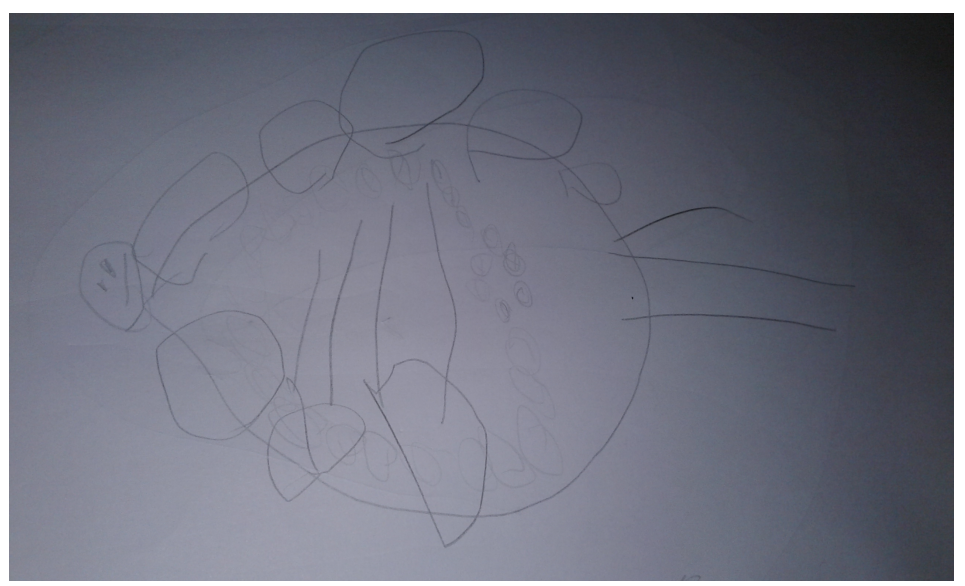

Photograph 14. A ladybug

One of these drawings was a ladybug. She saw many lady bugs on trees, flowers or grass. She put ladybugs on her hand and liked to watch them while walking and observed how they moved. (Photograph 14)
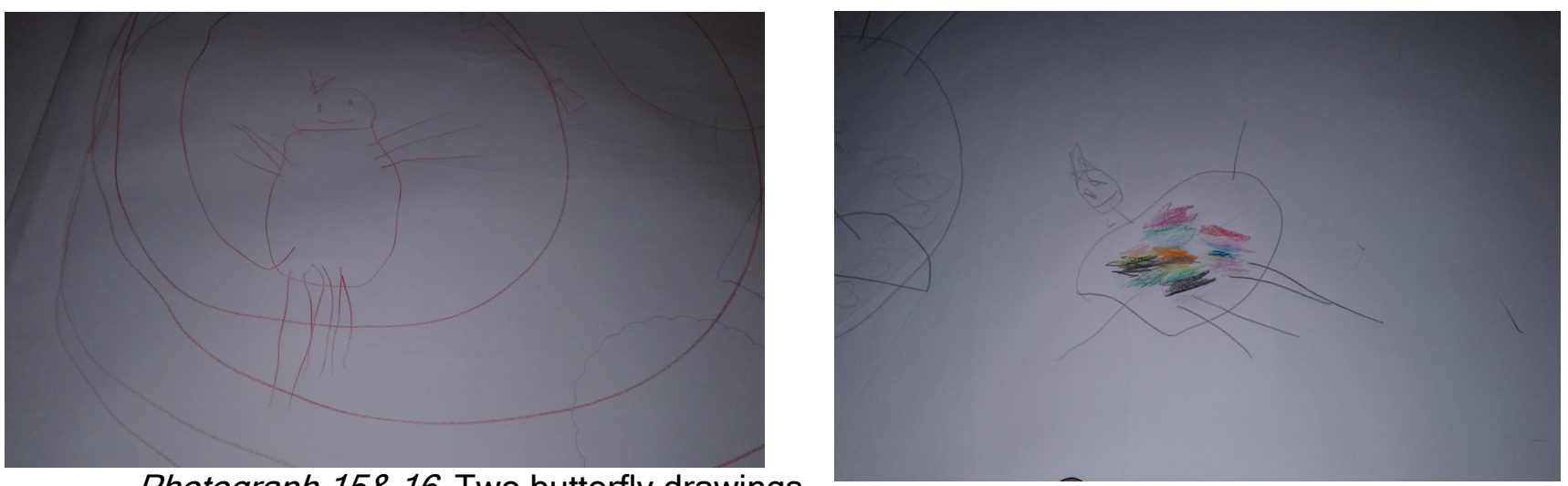

Photograph 15\& 16. Two butterfly drawings

One another drawing was a butterfly. She named the first (left) one as a butterfly in front of the water'. This should be a monarch butterfly because monarch butterflies are very common in New Zealand. They have big black and orange wings. (Science Learning Hub, 2018) That was why she coloured the second butterfly. There were also swan plants at my daughter's kindergarten. Children could observe how caterpillars were fed 
up on swan plants, grew up and turned to monarch butterflies. She saw these butterflies at kindergarten and later she especially observed, chased and tried to hold them. (Photograph 15 and 16)

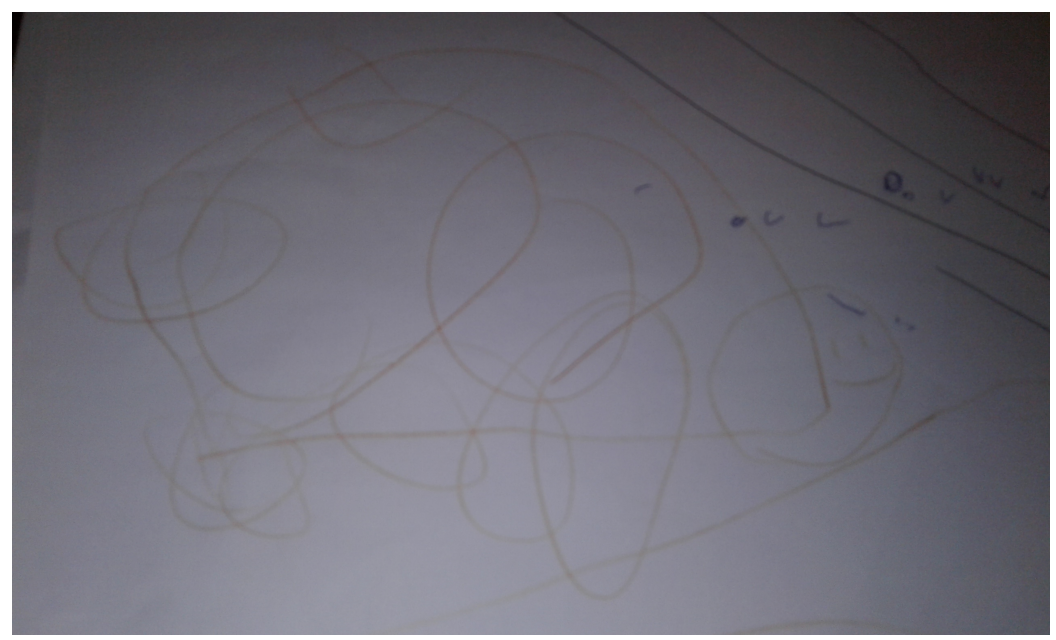

Photograph 17. A seaturtle

The other drawing was a sea turtle. (Photograph 17) My daughter was always keen on to see sea creatures and read books related to them. She saw a wounded sea turtle when we visited a rehabilitation centre in Turkey in 2017 and she also touched it. Probably these events triggered her imagination because she drew sea turtles many times. She might identify herslef with a sea turtle because she always preferred to draw 'a daddy sea turtle, a mommy sea turtle and a baby sea turtle' together.

\section{Self-confidence}

Both observers mentioned how participant's self-confidence increased by the time. The teacher's observation in week 10 was:

"When you first started in the bush, you were hesitant and unsure as to what was about to unfold. You now finish the Bush Explorers programme with a stronger relationship with the natural environment and a deeper knowledge of your own place in the environment."

The researcher's observation about the participant at the end of the bush explorer activity:

"It is very clear that you present a very rich learning environment for children by this activity. First, (the participant)'s vocabulary capacity has enriched and started to use different words such as fossil, tui, rangatira, Tane Mahuta, aroha, torch, shovel. Second, her kinesthetic learning ability developed. She is easily able to climb up and swing on climbing walls, flying fox, monkey bars and tree branches. Third, her affective development is amazing. She often uses/emphasizes 'aroha' and 'sharing'. She also is very kind and careful while playing with the other children. Fourth, she is more observant to natural environment. She always talks about birds, trees, worms, dogs and rubbishes." 


\section{Results and Discusion}

There are five defined themes within the research: observing, exploring, cognitive development, creativity and self-confidence. All results are coherent with the literature (Cooper, 2015; Brodin\& Lindstrand, 2006; Louv, 2005; Waite, 2009). Especially Louv (2005) points out all five themes in his book. Cooper (2015) and Carson (1956) emphasize how important unstructured outdoor plays are on the development of observation skills of children. Children can explore while observing the natural environment (Carson, 1956; Waite, 2009). Emily could explore the natural environment while observing different creatures such as ants, ladybugs, dragonflies. Those creatures affected Emily's imagination, too (Brodin\& Lindstrand, 2006). She drew lots of pictures related to creatures which she saw in the natural environment. The literature also says outdoor plays might be positive effect on science education (Cooper, 2015; Cullen, 1988; Stephenson, 1999). Emily could observe heavy and light pebbles. She realised which rocks she should throw and how objects might float. Emily could test her physical boundaries many times in outdoors and her self-confidence improved by the time (Cooper, 2015).

The research was conducted in NZ however there is not enough study related to unstructured outdoor plays in NZ. Most of the studies are at the theoretical level (Burke, 2008; Holdom, 2018; Kumar\& Whyte, 2018; O’Brein, 2015). However, outdoor plays are very popular in NZ and the results of this study are not enough. It is needed more experimental studies with control groups.

Both observations show that the participant has a sentimental connection (Carson, 1956; Louv, 2005; Waite, 2009) with natural environment by unstructured outdoor plays and she might learn science and art via outdoors (Brodin \& Lindstrand, 2006; VandermaasPeeler \& McClain, 2015). Emily wanted to touch the animals and nurture them. There are many environmental education programmes all over the world, they also have positive outputs but then again, we still have environmental problems. It means something does not work on these environmental education processes. This situation might be related to environmental education programmes which are carried out under capitalist economy (Misiaszek, 2018). These subjects are out of the scope of the research. However, capitalist economy is also close relationship with mass culture and media. (Horkheimer\& Adorno, 2002) Outdoor education is considered one of the ways to get rid of the negative effects of the media.

Media is very effective on everyone, especially on children (Potter, 2005; Roberts\& Foehr, 2008) and it affects our every decision, what we should put on, eat or which party we should vote (Horkheimer\& Adorno, 2002). Children who are between 2-7 years-old cannot differentiate real and virtual properly (Piaget,1981). They, therefore, are very open to media addiction. There are different kind of studies which show how media badly affects children such as violence, aggressive behaviour, obesity, computer game addiction (AAP, 2009; Berger, 2014; Chan, 2012; Aluja- Fabregat ve Beltri, 1998; Levine, 1998; Walters\& Zwaga, 2001).

One of the advantages of outdoor plays on preschoolers is to ignore media such as TV, i-pad (Brodin\& Lindstrand, 2006, Okur-Berberoglu, 2015b). My daughter watches TV like every child however she turns the TV off and asks me where we go to that day. There are a couple of important points here. First, we go outdoors regularly since her babyhood. Second, my daughter does not have any mobile phone, computer or i-pad so she does not know how to use them.

I am not a media-literacy specialist however in terms of education, outdoors might be used as an antidote for media effects. Cooper (2015), Powers (2004), Louv (2005), Brodin and Lindstrand (2006) emphasize different positive outputs of outdoors on 
children. Literature usually mentions structured outdoors plays and education however Louv (2005) especially emphasizes to focus on the effect of unstructured outdoors plays on children. My observation is important in terms of Louv's perspective because I have not seen yet any research related to unstructured outdoor plays.

Unstructured outdoor plays might have some negative points. Outdoor plays might take a couple of hours; for my case it took at least three hours. Parents should prepare extra foods and spare clothes for children and themselves because they do not know what the child wants to play. Parents always must watch the child in terms of health and safety. They cannot have extra occupation (eg. looking at mobile phone, surfing on the internet) while playing in outdoors. Parents might get bored while the child plays. Parents are not always able to join the play and they, therefore, are in outdoors only for the kid. If it is possible, they must go outdoors in every weather condition. According to my observation, children get tired while playing in outdoors and prefer to sleep rather than watching TV.

I did not aim to write a research paper while observing my daughter. However, when I checked out our photographs, I realised that we did different activities together. I might direct her to outdoors unconsciously because of my educational background but then again, I would like to share my observations and experiences. I know that every step of a research is difficult and in terms of observation, we might not be together with observee 24/7.

I do not want to show how I am a good mother here. In terms of qualitative approach and post-positivist perspective, research gets harder if the observee is human because there is no controlled laboratory environment for human. (Horkheimer\& Adorno, 2002) I,therefore, would like to merge my motherhood advantage and educational background together because nearly I am with my daughter 24/7; I do not need an ethical permission and know how to observe someone according to my aims. All my observation results are open to discussion and researchers need to do more studies.

\section{References}

Ali, A., Pigou, D.,Clarke, L., \& McLachlan, C. (2017). Literature review on motor skill and physical activity in preschool children in New Zealand. Advances in Physical Education, 7, 10-26. https://doi.org/10.4236/ape.2017.71002

Aluja-Fabregat, A., \& Torrubia-Beltri, R. (1998). Viewing of mass media violence, perception of violence, personality and academic achievement. Personality and Individual Differences, 25(5), 973-989.

American Academy of Pediatrics- AAP (2009). Policy Statement- Media Policy. $\begin{array}{lllll}\text { Pediatric, } & 124 & \text { (5), } & \text { 1495-1503. Retrieved from }\end{array}$ http://public.psych.iastate.edu/caa/abstracts/20052009/09AAPpolicy.pdf

Berger, A. A. (2014). Media Analysis Techniques. San Francisco: Sage Publications.

Brodin, J. \& Lindstrand, P. (2005). Children's learning in outdoor environments. Paper presented at the Early Childhood 11th Biennal Conference, Cyprus University, Nicosia, August 23 rd -26 th 2005.

Brodin, J., \& Lindstrand, P. (2006). Inclusion of children in outdoor education. Learning in Motion, Report I., TKH- report No. 43, Child \& Youth Science. Stockholm: Stockholm Institute of Education.

Burke, R. (2008). Becoming individuals together: Socialisation in the Japanese preschool. Sites: a journal of social anthropology and cultural studies, 5(2), 135160. 
Chan, K. (2012). Consumerism and Gender in Children's TV in Sexy Girls, Heroes and Funny Losers: Gender Representations in Children's TV around the World (Ed. Maya Götz\& Dafna Lemish). Peter Lang, Frankfurt.

Carson, R. (1956). The sense of wonder. New York: Harper \& Row.

Conezio, K., \& French, L. (2002). Science in the preschool classroom. Young children, $57(5), 12-18$.

Cooper, A. (2015). Nature and the outdoor learning environment: The forgotten resource in early childhood education. International Journal of Early Childhood Environmental Education, 3(1), 85-97. Retrieved from https://files.eric.ed.gov/fulltext/EJ1108430.pdf

Cullen, J. (1988). Preschool children's learning strategies. Set: research information for teachers, 2.

Duignan, M., Signal, L., \& Thomson, G. (2014). Good intentions, but inadequate practices-sun protection in early childhood centres, a qualitative study from New Zealand. NZ Med J, 127, 40-50. Retrieved from http://www.nzma.org.nz/journal/read-the-journal/all-issues/2010-2019/2014/vol127-no.-1389/5998

Engdahl, K. (2005). We want to live - live forever. An empirical study on children's interaction and play on two preschool playgrounds]. Report 41, TKH, Stockholm Institute of Education.

Fröbel, F. (1895). Friedrich Froebel's pedagogics of the kindergarten (Vol. 30). D. Appleton.

Gerritsen, S. (2016). Nutrition education for early childhood managers, teachers and nursery cooks: a prerequisite for effective obesity prevention. Public Health, 140, 56-58. doi: 10.1016/j.puhe.2016.05.025

Hemara, W. (2000). Maori Pedagogies. Wellington: New Zealand Council for Educational Research.

Holdom, J. (2018). Science, technology, engineering and mathematics learning through the lens of Te whāriki: He whāriki mātauranga mō ngā mokopuna o Aotearoa: Early childhood curriculum. He Kupu 5(3), 1-11. Retrieved from https://www.hekupu.ac.nz/sites/default/files/2018-05/03\%20Holdom.pdf

Horkheimer, M. \& Adorno, T. W. (2002). Dialectic of enlightenment. Stanford University Press: California.

Kolb, D. A. (1984). Experiential Learning: Experience As The Source Of Learning And Development, Prentice Hall Inc., EnglewoodCliffs, New Jersey. Retrieved from http://academic.regis.edu/ed205/Kolb.pdf , 03.06.2011

Kraft, R. J. \& Kielsmeier, J. C. (1995). Experiential Learning. Kendall/ Hunt, lowa.

$\mathrm{Ku}, \mathrm{H}$. Y. (2011). Measuring the Physical Activity of Children aged 3 to 7 years (Doctoral dissertation, University of Otago).

Kumar, K., \& Whyte, M. (2018). Interactive science in a sociocultural environment in early childhood. He Kupu, 5(3), 20-27. Retrieved from https://www.hekupu.ac.nz/sites/default/files/201805/04\%20Kumar\%20and\%20Whyte.pdf

Levine, M. (1998). See No Evil: A Guide to Protecting Our Children from Media Violence. San Francisco: Jossey-Bass Publishers.

Lindstrand, P. (2004). Playground and outdoor play. A literature review. Research report 42 in the series TKH. Stockholm: Stockholm Institute of Education: Department of Human development, learning and special education.

Louv, R. (2005). Last child in the woods. North Carolina: Algonquin Books of Chapel Hill.

McCulloch, D. (2009). A history of Christianity. The three thousand years. Dublin: Penguin Irlanda.

McLachlan, C. (2013). Children's learning and development in New Zealand: physical, cognitive and socio-emotional perspectives. The engine of the new New Zealand 
lecture series. Retrieved from http://www.masseyuniversity.co.nz/massey/fms/Colleges/Institute\%20of\%20Ed ucation/Documents/2013/web\%20copy Claire\%20McLachlan\%20commemorat ive\%20book.pdf

McClain, C., \& Vandermaas-Peeler, M. (2016). Outdoor Explorations with Preschoolers: An Observational Study of Young Children's Developing Relationship with the Natural World. International Journal of Early Childhood Environmental Education, 4(1), 37-53. Retrieved from https://files.eric.ed.gov/fulltext/EJ1120151.pdf

Ministry of Health (2017). Sit Less, Move More, Sleep Well: Active play guidelines for under-fives. Wellington: Ministry of Health. Retrieved from https://www.health.govt.nz/system/files/documents/publications/active-playguidelines-for-under-fives-may17.pdf

Misiaszek, G. W. (2018). Educating the global environmental citizen: Understanding ecopedagogy in local and global contexts. New York: Routledge.

New Zealand Birds (2018). Tui. Retrieved from http://www.nzbirds.com/birds/tui.html

O'Brien, N. (2015). Strategies for teachers developing strategies for mathematics in early childhood education. He Kupu, 4(1), 18-22. Retrieved from https://www.hekupu.ac.nz/sites/default/files/2017-10/Strategies-for-teachersdeveloping-strategies-for-mathematics-in-early-childhood-education.pdf

Okur, E. (2012). Outdoor experiential education: Ecology application. Published PhD Thesis, Canakkale Onsekiz Mart University Institute of Educational Sciences.

Okur-Berberoglu, E., Güder, Y., Sezer, B., \& Yalcin-Özdilek, Ş. (2013). An outdoor hydrobiology activity's effect on students' affective perspective, case study: Çanakkale, Science Camp. Kastamonu Education Journal, 21(3), 1177-1198.

Okur-Berberoglu, E. (2015a). Some suggestions for Turkey within the scope of outdoor education success of New Zealand. Journal of Turkish Science Education, 12 (3), 51-64.

Okur-Berberoglu, E. (2015b). Children-teenagers, media addiction and outdoor education. The Journal of Hasan Ali Yücel Faculty of Education, 12 (2), 45. Retrieved from http://dergipark.gov.tr/iuhayefd/issue/8803/110050

Okur-Berberoglu, E. (2017). Outdoor Experiential Environmental Education: An AdultCentred Intervention for the Affective Domain. International Electronic Journal of Environmental Education, 7(1), 34-58.

Oliver, M., Schofield, G. M., Kolt, G. S., \& McLachlan, C. (2007). Physical Activity in Early Childhood: Current State of Knowledge. New Zealand Research in Early Childhood Education, 10, 47-68. Retrieved from https://www.childforum.com/images/stories/Oliver et al 2007.pdf

Oliver, M. (2008). Physical activity in New Zealand preschoolers: amount, associations, and accounts (Doctoral dissertation, Auckland University of Technology).

Piaget, J. (1981). Intelligence and affectivity: Their relationship during child development. (Trans \& Ed TA Brown \& CE Kaegi). Annual Reviews.

Potter, W. J. (2005). Media Literacy (3rd Edition). London: Sage Publication.

Powers, D. L. (2004). The Effects of An Outdoor Education Program on Life Effectiviness Skills of Participant. Master of Science Thesis, California State University, USA.

Roberts, D. F., \& Foehr, U. G. (2008). Trends in media use. The future of children, 1137.

Raustorp, A., Pagels, P., Boldemann, C., Cosco, N., Söderström, M., \& Mårtensson, F. (2012). Accelerometer measured level of physical activity indoors and outdoors during preschool time in Sweden and the United States. Journal of physical activity and health, $9(6)$, 801-808. Retrieved from https://pdfs.semanticscholar.org/7257/5d82ccd7606b17fa2d64efc8e1a579aa4e 34.pdf

Shanely, S. D. (2006). Towards An Understanding Of An Outdoor Education Program: Listening To Participants' Stories. PhD Thesis, University of Florida, USA. 
Siraj-Blatchford, J. \&; MacLeod-Brudenell, I. (1999). Supporting Science, Design And Technology (Editors: Vicky Hurst and Jevefer Joseph). Buckhingham: Open University Press.

Stephenson, A. (1999). Opening up the outdoors: A case study of young children's outdoor experiences in one childcare centre. M. Ed Thesis, Victoria University of Wellington.

Retrieved

from http://researcharchive.vuw.ac.nz/bitstream/handle/10063/917/paper.pdf?seque nce $=1$

Stine, S. (1997). Landscapes for learning. New York: John Wiley\&Sons, Inc.

Stufflebeam, D. L. (2001). Evaluations models. New Directions for Evaluation, Spring $200189, \quad 7-98 . \quad$ Retrieved from http://onlinelibrary.wiley.com.ezproxy.waikato.ac.nz/doi/10.1002/ev.3/pdf.

Te Whāriki, Early Childhood Curriculum of New Zealand (2017). Ministry of Education 2017 Revision. Retrieved from https://www.education.govt.nz/assets/Documents/Early-Childhood/Te-WharikiEarly-Childhood-Curriculum-ENG-Web.pdf

Vandermaas-Peeler, M., \& McClain, C. (2015). The Green Bean Has to Be Longer than Your Thumb: An Observational Study of Preschoolers' Math and Science Experiences in a Garden. International Journal of Early Childhood Environmental Education, 3(1), 8-27. Retrieved from https://files.eric.ed.gov/fulltext/EJ1108468.pdf

Waite, S. (2009, April). Outdoor learning for children aged 2-11: Perceived barriers, potential solutions. In Fourth International Outdoor Education Research Conference, La Trope University, Beechworth, Victoria, Australia (pp. 15-18). Retrieved

from https://www.researchgate.net/profile/Sue Waite/publication/242494391 Outdo or learning for children aged 2-

11 perceived barriers potential_solutions/links/0deec5300881a079f8000000.p df

Wilson, R. A. (1996). Starting Early: Environmental Education during the Early Childhood Years. ERIC Digest. Retrieved from https://files.eric.ed.gov/fulltext/ED402147.pdf

Walters, R. \& Zwaga, W. (2001). The Younger Audience. New Zealand: Dunmore Printing Company.

Wood, J. M. (2007). Understanding and computing Cohen's Kappa: A tutorial. WebPsychEmpiricist. Retrieved from http://wpe.info/papers_table.html

Yıldırım, G., \& Akamca, G. Ö. (2017). The effect of outdoor learning activities on the development of preschool children. South African journal of education, 37(2). Retrieved from https://www.ajol.info/index.php/saje/article/download/157298/146909

Yildirim, A. \& Simsek, H. (2006). Qualitative methods for social science. Ankara: Seckin Publication.

Young, L. (2017). Under 5 Energize: Improving child nutrition and physical activity through early childhood centres (Doctoral dissertation, Auckland University of Technology). http://aut.researchgateway.ac.nz/bitstream/handle/10292/11003/YoungL.pdf?s equence $=4 \&$ isAllowed $=y$

Zanovello, I. (1999). Outdoor and Environmental Education Centres: A Case Study of Starthcona Park Lodge and Outdoor Education Centre, British Columbia, Canada. A Master Degree Thesis, Faculty of Environmental Design, The University of Calgary, Alberta. 


\title{
Yapılandırımamış Sınıfdışı Oyunların Bir Çocuk Üzerine Bazı Etkileri: Yeni Zelanda'dan Bir Örnek Olay Incelemesi
}

\author{
Emel Okur- Berberoglu \\ LIC (Livestock Improvement Corporation), Hamilton, NEW ZEALAND
}

\begin{abstract}
Özet
Sınıfdışı eğitim, son zamanlarda popüler olan eğitim konularından birisidir ve macera eğitimi, doğa eğitimi, deneyimsel eğitim ya da müze eğitimi gibi diğer bazı kavramlarla eş anlamlı olarak kullanılmaktadır. Sınıfdışı eğitim, ayrıca araştırmacılar tarafından örgün eğitimin bir tamamlayıcısı ve zengin bir öğrenme ortamı olarak görülmektedir. Alanyazin, sınıfdışı eğitimin olumlu çıktılarından bahsetmektedir fakat bu alanda yapılmış pek fazla araştırma bulunmamaktadır. Bu araştırmanın amacı, Yeni Zelanda'da yapılandııılmamış sınıfdışı oyunların, okul öncesi seviyesinde bir çocuk üzerine bazı etkilerini incelemektir. Yöntem olarak, örnek olay incelemesi kapsamında nitel yaklaşım kullanılmıştır. Araştırmanın sonunda inceleme, keşfetme, bilişsel gelişim, yaratıcılık ve kendine güven temaları belirlenmiştir. Bu alanda, daha fazla kontrol gruplu çalışma yapılmasına ihtiyaç bulunmaktadır.
\end{abstract}

Anahtar Kelimeler: Yapılandırımamış oyun, sınıfdışı eğitim, okul öncesi çocuklar, Yeni Zelanda 